CZASOPISMO INŻYNIERII LA¿OWEJ, ŚRODOWISKA I ARCHITEKTURY JOURNAL OF CIVIL ENGINEERING, ENVIRONMENT AND ARCHITECTURE

JCEEA, t. XXXIV, z. 64 (3/II/17), lipiec-wrzesień 2017, s. 305-314, DOI:10.7862/rb.2017.174

\author{
Yaroslav SHYDLOVSKYI ${ }^{1}$ \\ Bogdan DEMCHYNA ${ }^{2}$ \\ Mykhaylo SURMAY ${ }^{3}$
}

\title{
EXPERIMENTAL RESEARCH OF WOODENARCHES
}

\begin{abstract}
This paper presents the findings of the pilot studies of two-hinged wooden arches. The prototype models of wooden arches with the span of $6 \mathrm{~m}$ and the rise of $1 \mathrm{~m}$ were designed. The models had a rectangular cross-section of $180 \times 40 \mathrm{~mm}$ and a T-section of $180 \times 40 \mathrm{~mm}$ with a plywood plate with the thickness of $6 \mathrm{~mm}$ and the width of $500 \mathrm{~mm}$. The main objective of the T-section was to ensure the stability of the arch. Each arch was composed of six segments - boards joined by clamping plates. The bowstring truss including two inclined tie bars enables carrying asymmetric loads and provides in-plane stability of the arch. A methodology for laboratory testing of the prototype models of wooden arches subjected to different types of loads was developed. Two prototypes of wooden arches were tested with rectangular cross-sections and two T-section ones subjected to the loading across the span, and two prototypes subjected to the half-span loading. In total, eight arches were tested. Deflections of arches, cross-section deformations and arch thrust force were recorded. The arches were tested until failure. The results of testing revealed insufficient stability of the arches with rectangular cross-section in the horizontal plane. For the arches with T-section the whole arch rib was damaged, the in-plane stability was ensured by the T-section. The collapsing force of the T-section arch was about 1.3times greater than the collapsing force of the rectangular section arches.
\end{abstract}

Keywords: clamping plate, board, methodology, pilot study

\footnotetext{
${ }^{1}$ Yaroslav Shydlovskyi, student, Lviv Polytechnic National University, 2/13 Sharanevych St., Lviv, Ukraine

${ }^{2}$ Bogdan H. Demchyna, Lviv Polytechnic National University, 6 Karpinskyy St., Lviv, Ukraine

${ }^{3}$ Mykhaylo Surmay, lecturer, Lviv Polytechnic National University, 6 Karpinskyy St., Lviv, Ukraine
} 


\section{Topicality of the study and problem statement}

This study presents the design of a wooden plank arch with horizontal and angular tie bars connected by clamping plates.

The arch rib segments are connected by clamping plates, which ensures simplicity of construction design and reduction of weight, and guarantees a secure joint connection. This connection method is widespread in the EU and America.

The use of the system of horizontal and angular tie bars developed by V.H. Shukhov [1] allows us to reduce the weight of bearing structures, speed up and simplify construction, without reducing the load bearing capacity of the structure. Further studies should be done in order to improve design and implementation wooden arches.

An important aspect of this work is the study of the T-section arches. The T-section is easily made by placing plywood in the upper area of rectangular cross-section made up of boards. By means of such a cross-section of the arch rib the in-plain stability of arch is achieved. In addition, this solution does not lead to the significant increase of the construction weight, which is essential for this type of construction.

\section{Prototype model design}

Two series of wooden arches were designed. The first series of arches had a rectangular cross-section type A-1...4 (Fig. 1a), the second one had a T-section type At-1...4 (Fig. 1b). Each of the series consisted of four prototypes of arches.

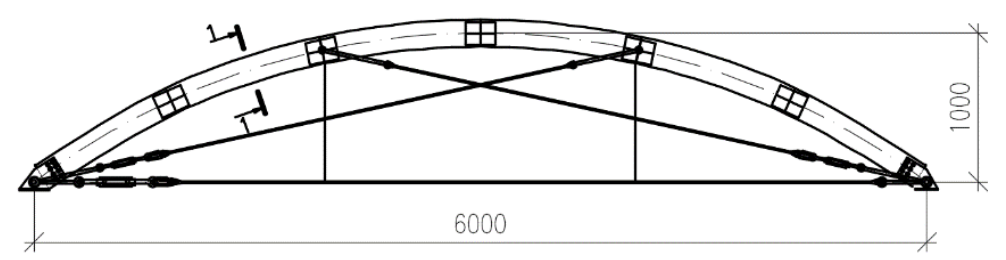

1-1
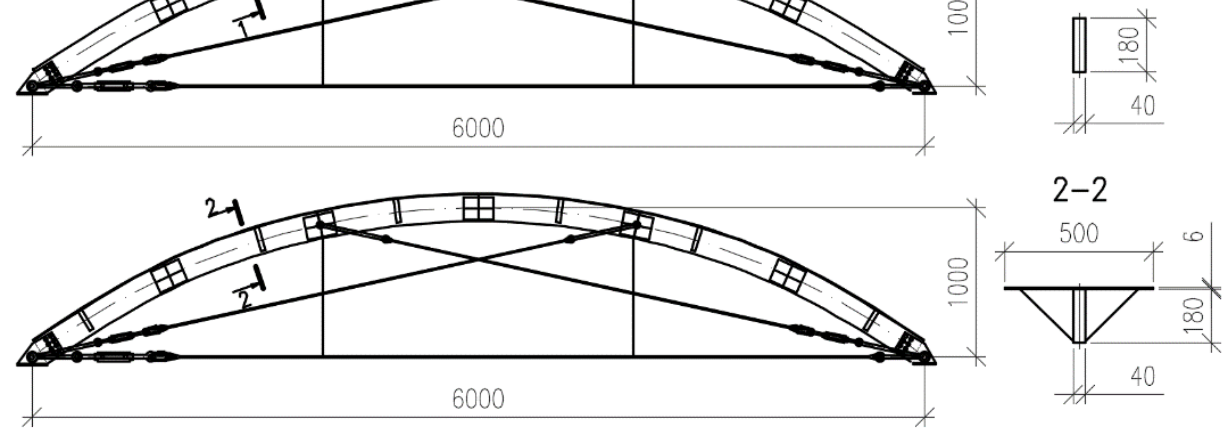

Fig. 1. Series of arches: a) with rectangular cross-section; b) with T-section 
The arch span was set based on the dimension of modular system used in construction. Therefore, the span of the wooden arch was $6 \mathrm{~m}$. All the arches had the rise of $1 \mathrm{~m}$. The structure of the arches consisted of six board segments.

Following the requirements abutment was made by means of 8 bolts with the diameter of $10 \mathrm{~mm}$ and the strength class of 5.8 (Fig. 2).

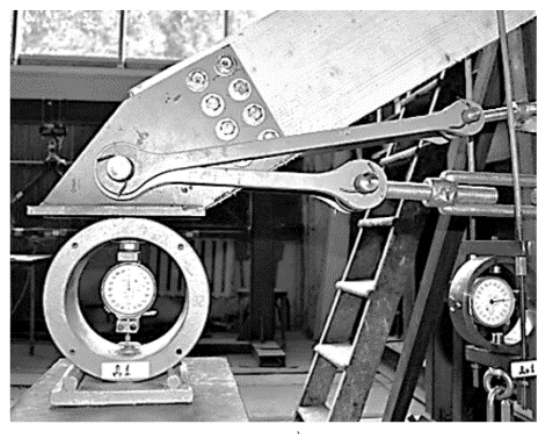

a)

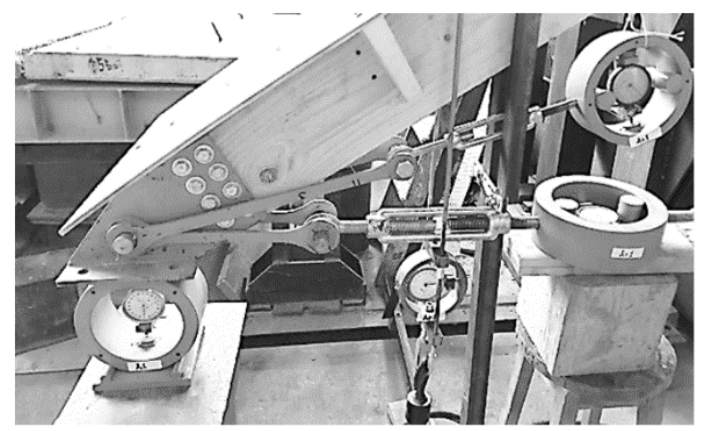

b)

Fig. 2. View of the abutment to wooden arches: a) $\operatorname{arch}$ A-1; b) $\operatorname{arch}$ At-1

All board segments were connected by clamping plates with the dimensions of $76 \times 200 \times 1,5 \mathrm{~mm}$, adjusted to both sides and pressed using press $2 \Pi \Gamma-100$ (Fig. 3).

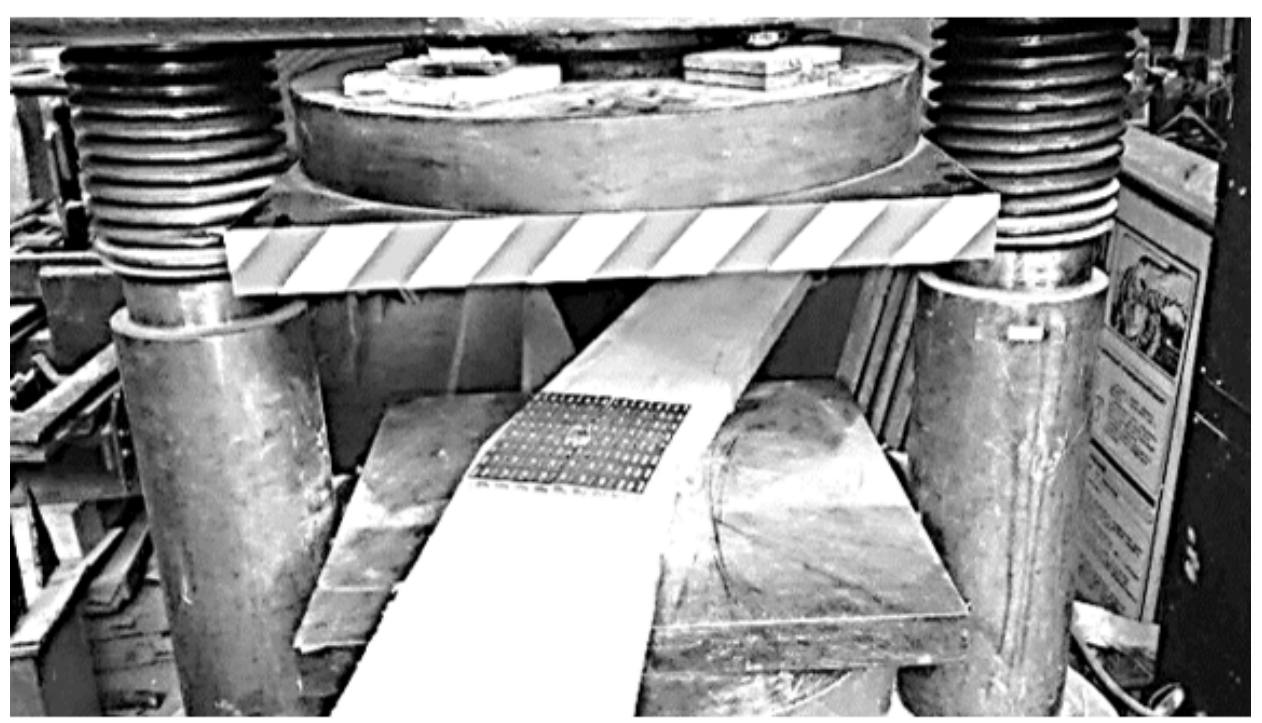

Fig. 3. The process of pressing of clampingplatesusingpress $2 П Г-100$ 
To fix the horizontal and angular tie bars a special design of abutment was developed. This enabled hinging tie bars. For angular ties, which were to be hinged in the plane of the arch, metal parts were designed that were installed in the arch during its erection and served as the hinge joint (Fig. 4).

In order to prevent the problem of losing the in-plain stability of the arch, we developed a system of angles for its horizontal unfastening with the increment of $1 \mathrm{~m}$.

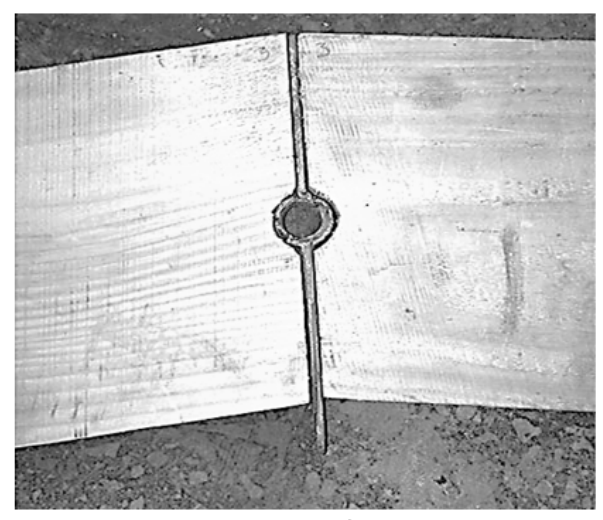

a)

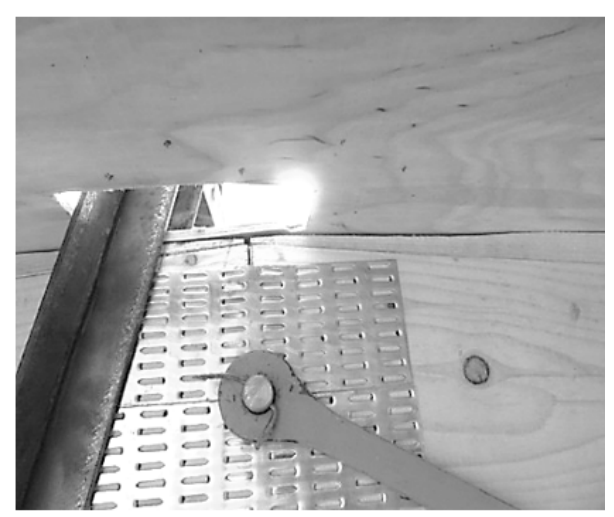

b)

Fig. 4. View of the hinge joint of angulartiesbars: a) beforeinstallingclampingplates; b) actualhinge joint

Fixing top plate for arches Ат with T-section was made by fastening plywood sheet $\Phi K 6 \mathrm{~mm}$ to the prepared board arch with the cross-section of $180 \times 40 \mathrm{~mm}$ using screws. In addition, along the arch rib we fixed 6 angle stiffeners made of wooden boards with the thickness of $40 \mathrm{~mm}$ and the increments of $1 \mathrm{~m}$ to plywood and boards of the ribs of the arches. The main task of the T-section of the ribs of the arches was to ensure their stability, which led to the increase of bearing capacity of arches.

\section{The test stand}

The pilot study of the wooden arches with various cross-sections was conducted in the laboratory of the Department of building construction and bridges of Lviv Polytechnic National University. For this purpose, a special test stand was designed [2] (see Fig. 6). A load was applied to the prototype models by six hydraulic jacks Miol 80-450, the maximum load was 5t. These jacks worked together with a pump station. The general view of the test stand is shown in Fig. 5, a device layout is given in Fig. 6. 
a)

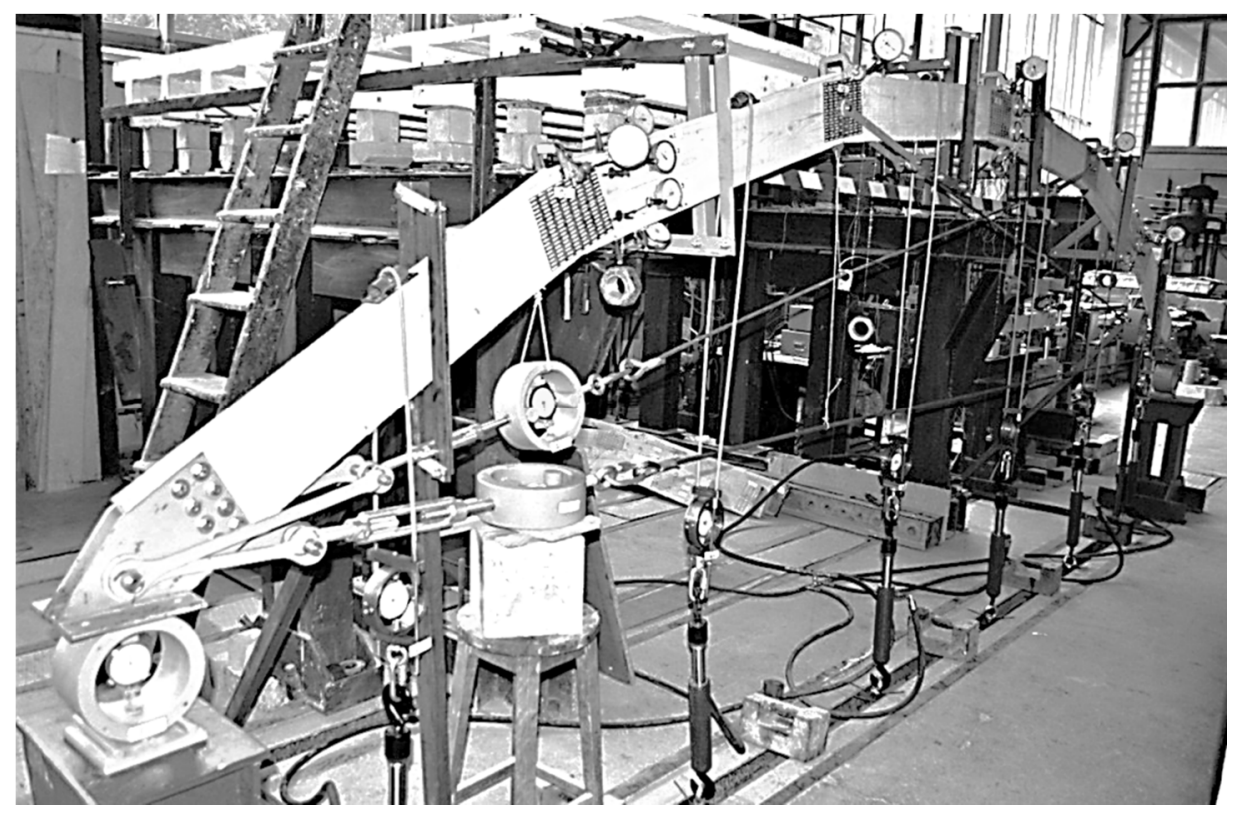

b)

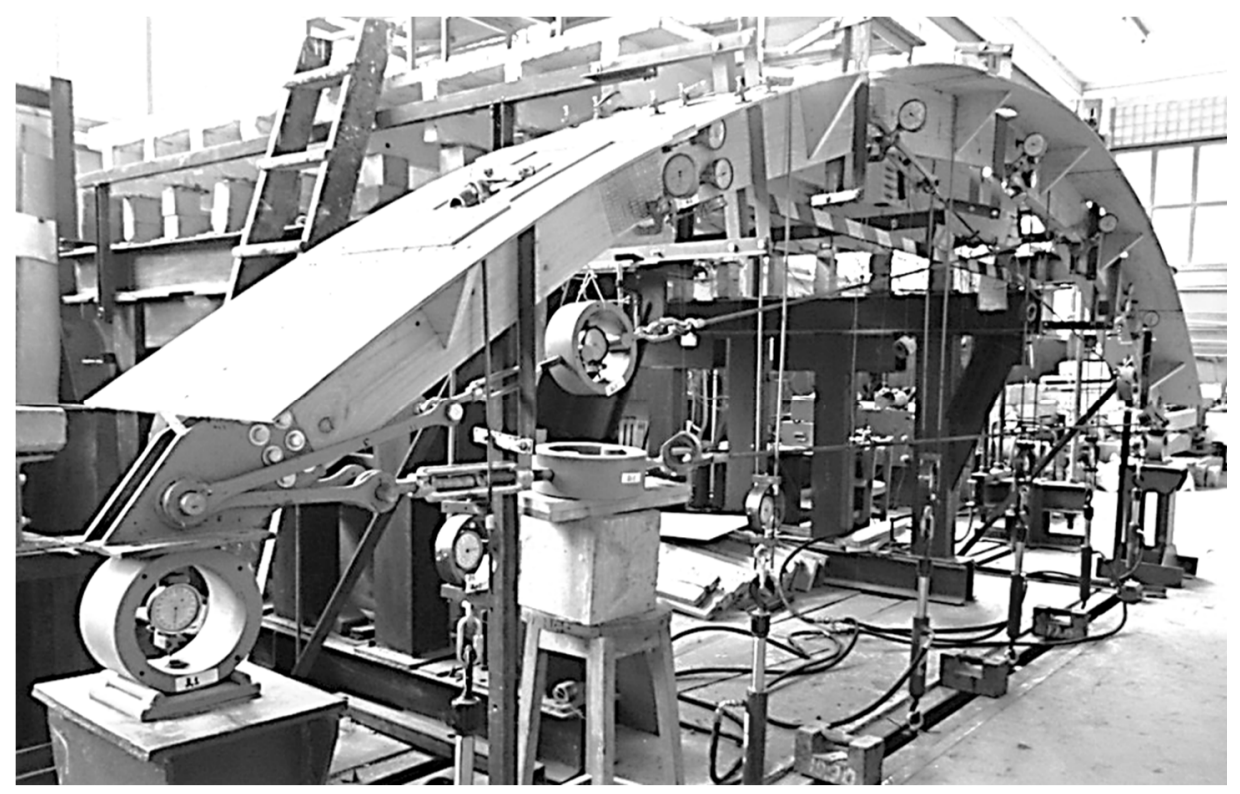

Fig. 5. View of the prototype test stand: a) the arch of A type; b) the arch of At type. 
The stand for testing prototypes consisted of arch model (1); abutment (2) fixed to reinforced floor (3); dynamometers on abutment D1 and D2 (4); system of struts to ensure the stability of the arch (5); hydraulic jacks with the dynamometers of D 3... D8 (6); dynamometer D9 (7) on the horizontal tie bar (8); dynamometers D10, D11 (9) angular tie bars (10); micro dial gauge M1 ... M18 for rectangular cross-section and Mi1 ... Mi24 - for the T-section (11);

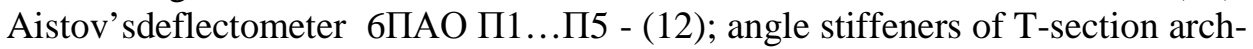
es (13).

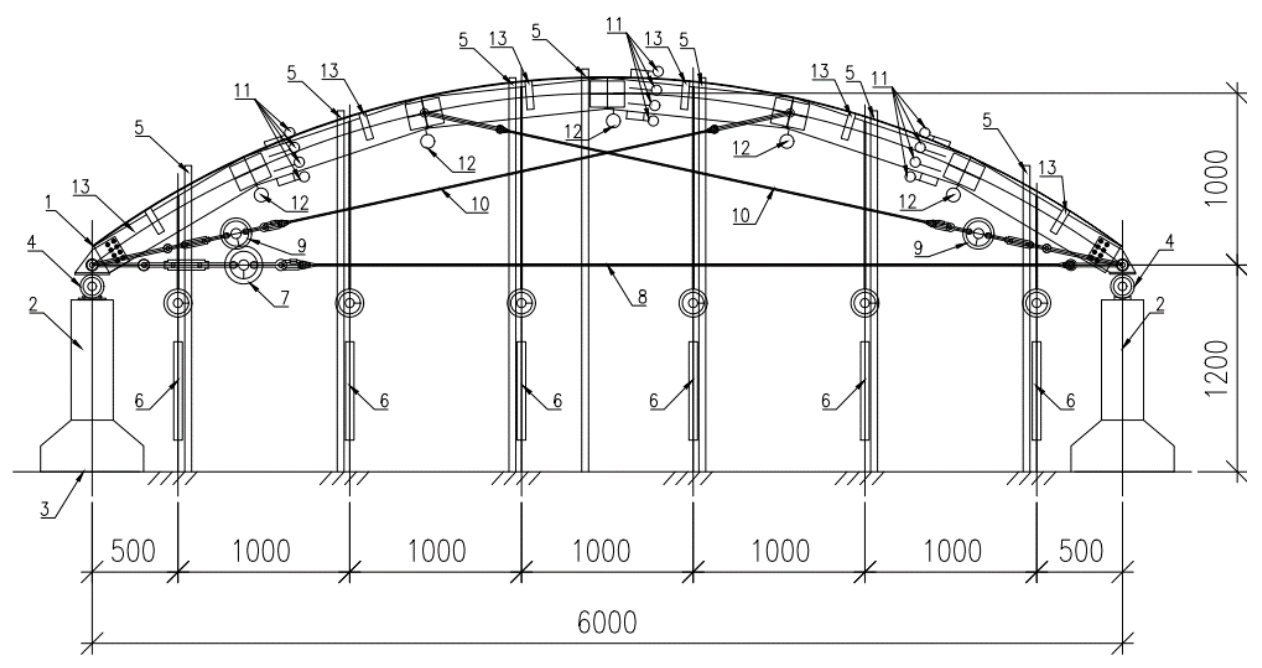

Fig. 6. The scheme of the test stand with the layout of devices 1 - archmadeup of boardsegmentsconnected by clampingplates (1); 2 - abutment, fixed to reinforcedfloor; 4 - dynamometers on abutment D1 and D2; 5 - system of struts to ensure the stability of the arch; 6 - hydraulicjacks with a dynamometer of D3 ... F8; 7 - dynamometer D9; 8 - horizontaltie bar; 9 - dynamometers D10, D11; 10 - angulartiebars; 11 - micro dialgauge Mi1 ... Mi18 for rectangular cross-section, micro dialgauge Mi1 ...Mi-24 for the T-section; 12 - Aistov'sdeflectometer 6ПАО P1...P5; 13 anglestiffeners of T-sectionarches

\section{Methodology for arch testing}

The study focused on the effect of symmetric (Fig. 7a) and asymmetric (Fig. 7b) loads.

The load was applied gradually in increments of $0.1 \mathrm{kN} / \mathrm{m}$. At each stage, in order to distribute and stabilize deformation, the load was maintained for 10-15 minutes, after that we took readings. 
a)
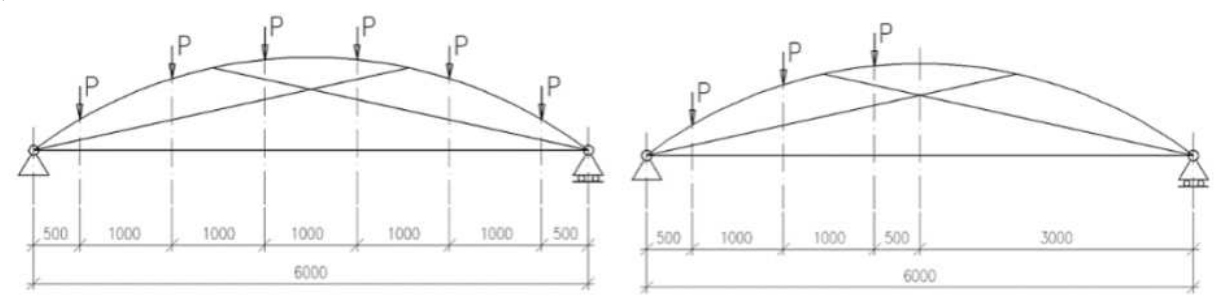

Fig. 7.Schemes of arches' loads: a) symmetrical; b) asymmetric

Using the installed devices we took the following readings:

- deflections u in five joints using Aistov'sdeflectometer 6ПАО with division value of $0.01 \mathrm{~mm}$ fixed with clamps to the arch;

- cross section fibre deformation and T-section plywood sheet deformation by means of micro dial gauge with division value of $0.001 \mathrm{~mm}$ in three specific sections A-A, B, C-C;

- bearing reaction using dynamometers on abutment (see Fig. 2);

- arch thrust force using dynamometers D9, D10, D11;

- the force of hydraulic jacks using dynamometers D3 ... 8 at each point of load application.

While testing arches' ribs we monitored the stability of the arches with different cross-sections in order to develop recommendations to ensure the stability of arches.

\section{The results of the experimental research}

The results of the pilot study on wooden arches are given in Table 1. The table presents the characteristics of breaking load and actual damage.

Table 1.

\begin{tabular}{|c|c|c|c|}
\hline Arch type & $\begin{array}{c}\text { Breaking load, } \\
\mathrm{kN} / \mathrm{m}\end{array}$ & Load type & Actual damage \\
\hline A-1.1 & 8,9 & \multirow{4}{*}{ symmetrical } & planebuckling \\
\hline A-2.1 & 9,5 & & planebuckling \\
\hline Ат-1.1 & 14,5 & & damage to board in abutment joint \\
\hline Ат-2.1 & 13,5 & & wood bearing failure \\
\hline A-3.2 & 10,0 & \multirow{4}{*}{ asymmetric } & planebuckling \\
\hline $\mathrm{A}-4.2$ & 11,0 & & damage to arch rib \\
\hline Ат- 3.2 & 13,3 & & damage to arch rib \\
\hline Ат- 3.2 & 13,5 & & $\begin{array}{l}\text { delaminationofplywoodandwood } \\
\text { bearing failure }\end{array}$ \\
\hline
\end{tabular}


The deflection of arch A-2.1, caused by the symmetric loading applied in the course of study, at the various stages of loading is given in Fig. 8. ing.

Figure 9 shows the deflection of arch A-2.2 caused by the half-span load-

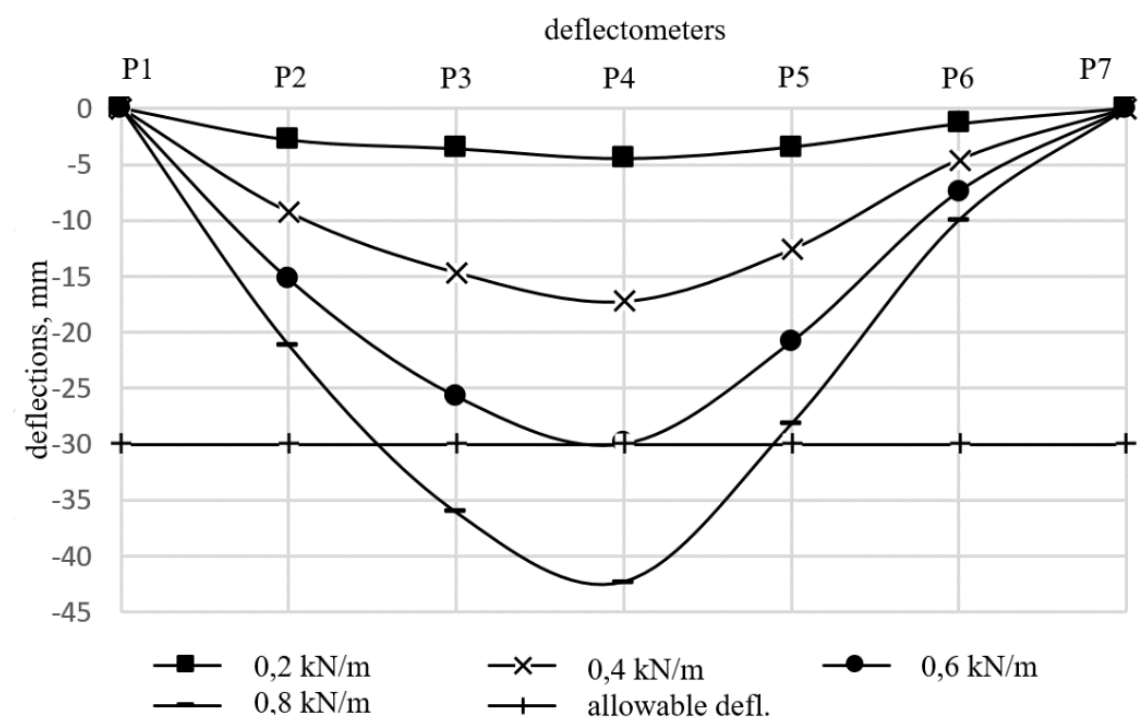

Fig. 8. Deflection of arch A-1 caused by symmetric loading

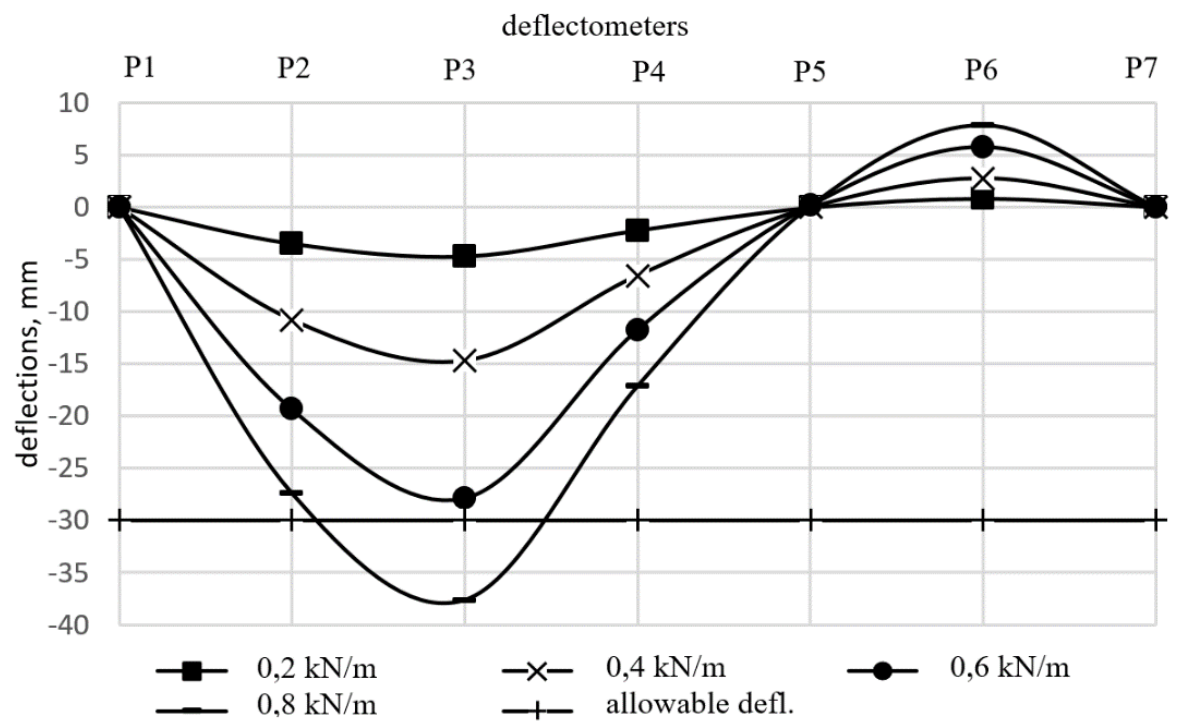

Fig. 9. Deflection of arch A-2.2 caused by the half-span loading 
The view of the damage to the arches after the studies is given in Fig. 10.
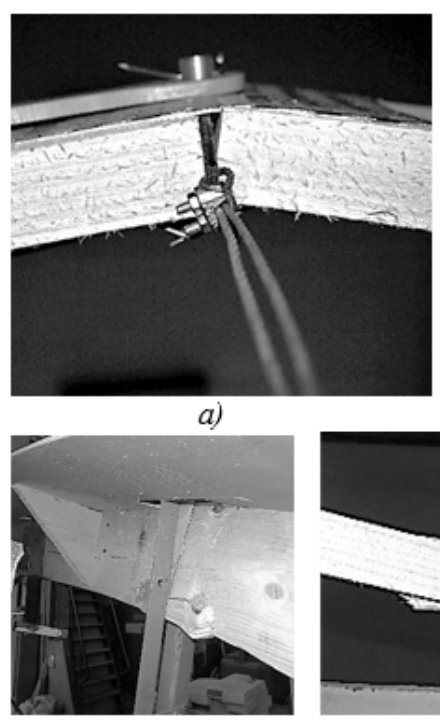

d)

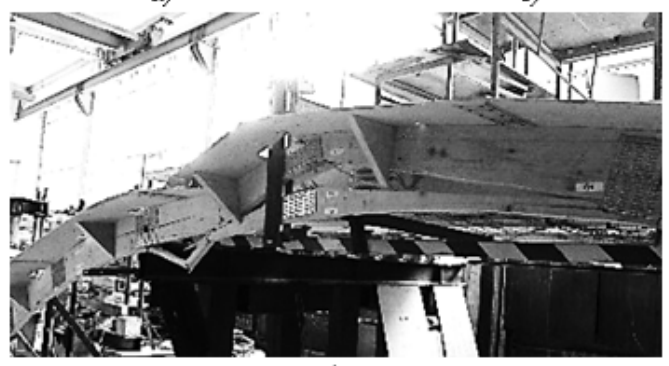

g)

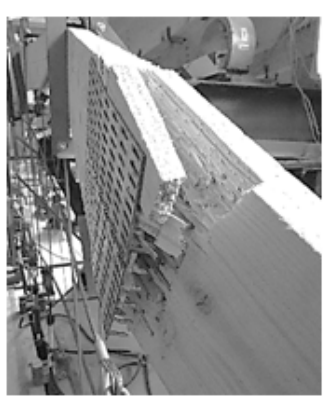

b)

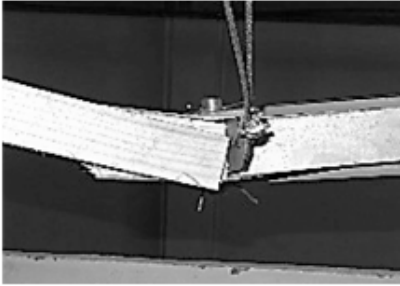

e)

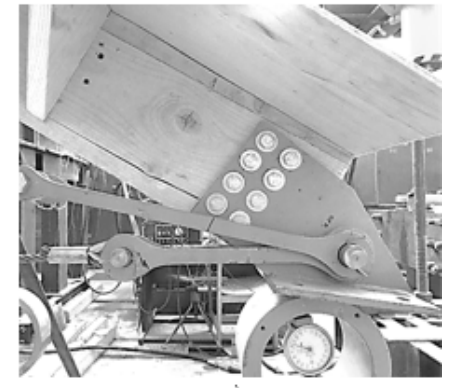

c)

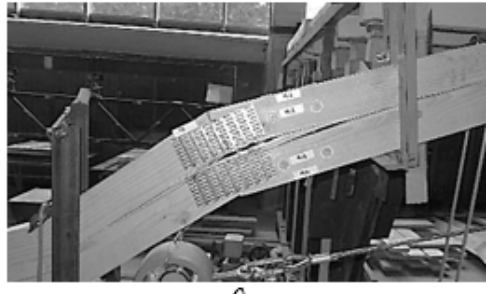

f)

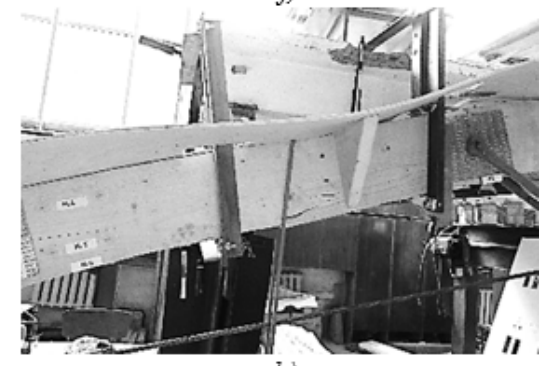

h)

Fig. 10. The view of arches after being damaged: a) A-1.1; b) A-2.1; c) At-1.1; d) At-2.1; e) A-3.2; f) A-4.2; g) At-3.2; h) At-4.2.

\section{Conclusion}

1) The design of a wooden arch with clamping plates, which is light, easy and fastto construct, and cost-effective, is proposed;

2) The methodology for the pilot studies of wooden arches on the effect of two types of loading, i.e. the symmetrical loading across the whole span of the arch and the asymmetric half-span one, was devised;

3 ) In course of the study we revealed that the in-plane stability of the arches with the T-section is greater compared to the arches with the rectangular crosssection, which caused damage to the ribs of arches;

4) The readings taken along the height of cross sections of arches, using micro dial gauge (M1 ... 24), should be further analysed. 


\section{Literature}

[1] Stroitelnaya mekhanika. Isbranye trudy, Shukhov V.G. M: Nauka, 1977.-193.

[2] Metodyka eksperementalnykh doslidzhen mitsnosti ta deformatyvnosti derevyanoi vanty, armovanoi stalnym trosom, A.P. Kravz, B.H. Demchyna, I.I. Lukach ta in. Teoria i praktyka budivnytstva. Vydavnytstvo Lvivskoi Pilitekhniky, 2012, 4s.

[3] Rekomendatsii po proektirovaniu i izhotovleniu doshchatykh konstrukstyi na MZP, TSNIISK im. Kucherenko. 1983. - 39.

\section{EKSPERYMENTALNE BADANIA DREWNIANYCH ŁUKÓW}

\section{Streszczenie}

W niniejszym artykule przedstawiono wyniki eksperymentalnych badań dwuprzegubowych drewnianych łuków. Skonstruowano badawcze modele drewnianych łuków o rozpiętości $6 \mathrm{~m}$ i strzałce $1 \mathrm{~m}$. Modele do badań miały przekrój prostokątny o wymiarach $180 x 40 \mathrm{~mm}$ oraz przekrój teowy ze środnikiem 180x40mm i półką ze sklejki o grubości $6 \mathrm{~mm}$ i szerokości $500 \mathrm{~mm}$. Głównym zadaniem przekroju teowego było zabezpieczenie stabilności łuku. Każdy łuk składał się z sześciu elementów - desek, które były połączone między sobą za pomocą płytek kolczastych. W łuku było poziome stężenie z kabla dla przeniesienia sił poziomych od rozporu konstrukcji oraz dwóch pochyłych stężeń z kabli dla przeniesienia niesymetrycznych obciążeń i zabezpieczenia stabilności w płaszczyźnie łuku. Opracowano metodę badania eksperymentalnych wzorców drewnianych łuków w warunkach laboratoryjnych na działanie różnych rodzajów obciążeń. Wypróbowano po 2 badawcze wzorce drewnianych łuków o przekroju prostokątnym i przekroju teowym na działanie obciążenia na całej rozpiętości, a także po 2 badawcze wzorce przy działaniu obciążenia na połowie rozpiętości. W sumie zbadano 8 łuków. W trakcie eksperymentu były odczytywane ugięcia łuku, odkształcenia w przekrojach poprzecznych oraz naprężenia rozciągające $\mathrm{w}$ stężeniach. Łuki były badane do całkowitego zniszczenia. W wyniku badań łuków o przekroju prostokątnym ustalono ich niedostateczną stabilność w poziomej płaszczyźnie. Łuki o przekroju teowym niszczyły się w przekroju łuku, ich stabilność z płaszczyzny była zabezpieczona przekrojem teowym. Niszczące obciążenia w łukach o przekroju teowym średnio były 1,3 razy większe od niszczących obciążeń łuków o przekroju prostokątnym.

Słowa kluczowe: płytka kolczasta, deska, metoda, badanie

Przestano do redakcji: 25.08.2017 r.

Przyjęto do druku: 01.09.2017 r. 